\title{
US at sixes and sevens over Soviet exchanges
}

LAST week, Dr Frank Press, the US presidential adviser on science, left for Moscow to discuss the progress of US-Soviet scientific cooperation.

The visit, as part of the regular programme of scientific cooperation inaugurated by the Nixon-Brezhnev agreement of 1974, was originally scheduled for last summer. It was cancelled at the last minute by President Carter in protest at the trial and conviction of Dr Yurii Orlov, the physicist, for human rights activities.

The Soviet science planners clearly welcome the restoration of full scientific relations with the US. Writing in Izvestiya, Dr Gvishiani, Deputy Chairman of the State Committee for Science and Technology stressed the "mutual benefit" of such exchanges and answered Western attempts to impede them. He maintained that technology transfer was not as is frequently alleged, a "one way flow"; several US firms, he said, were benefiting from Soviet technology.

At present, except for a few hardliners, there is little support among Western scientists for out-and-out boycott of the Soviet Union. Most would prefer to avail themselves of the opportunities provided by conferences in the Soviet Union to visit those of their colleagues who are dissidents and refusniks.

During 1978, however, some US academics claimed that the State Department and other relevant departments and agencies of the US government appeared to be implementing a policy of discouraging US scientists, who were visiting the Soviet Union as part of the official exchange programme, from contacting dissidents and refusniks.

It appears that pressure ranged from "friendly warnings" to the dismissal of certain known friends of the Soviet "opposition" from honorary but prestigious US government consultancies.
At the end of last year, the Committee for Concerned Scientists Inc., one of the most active human rights pressure groups, made representations to the State Department that this practice should cease. The committee was assured that no such policy in fact existed; if any such actions had been taken, it was on the mistaken initiative of individuals.

One result of the confusion of official US policy on the matter is that, on occasion, the Soviet hosts have been able to exert pressure on visiting scientists to stay away from opposition circles. In one case, a party of scientists was informed by the head of the Soviet welcoming committee that he had an "agreement" with the head of the US exchange programme in physics that scientists on official exchanges should not visit the Sunday seminar for refusniks. Challenged on the matter, the US official in question denied the existence of any such "agreement", as did also the National Academy of Sciences and the various government agencies in charge of exchanges.

If the idea of general boycott is abandoned, scientists concerned about human rights issues could take action by "working to rule" on the vexed question of substitutes. For many years Soviet delegates invited to attend conferences outside the USSR have been replaced by scientific nonentities. Originally, this resulted in free periods in the time-table, but gradually over the years it has become increasingly common for the substitutes to be accommodated in the programme.

Last summer, at the Paris conference on luminescence, a special "Round Table" on the Orlov case was held, and the possibility of a campaign against substitutes discussed. The consensus of opinion, however, was that it would cause too many practical difficulties, and possibly lead to Soviet withdrawals.

So far, only a few hard-liners, such as Nobel Laureate Paul Flery and his four co-protesters, who refused to attend the IFPAC seminar on Macromolecular chemistry in Tashkent, are prepared to make a stand on the "substitutes" issue.

However, a disturbing document issued recently by the Committee of Concerned Scientists may well make it necessary to reappraise the whole problem of substitutes. The report, alleging wide-spread anti-Semitism in Soviet mathematics, stresses that it is virtually impossible for Soviet Jewish mathematicians to travel abroad to conferences. This, it must be stressed, is not a matter of Jews who wish to emigrate to Israel, but simply of Soviet citizens with no "Zionist" inclinations who have a Jewish name and the entry "Jew" on their internal passport.

The Committee for Concerned Scientists strongly urge a "no-substitutes" policy as the best way of helping in such cases. Other countries of the Comecon bloc are, in the main, somewhat more lenient about foreign travel - with the notable exception of conferences held in Israel, which, since 1967, has had no diplomatic relations with any Comecon country except Romania. Poland is perhaps the most lenient of the Comecon countries. A handful of Polish ecologists managed to attend the Intecol-2 conference in Jerusalem last September. However, members of the Polish Biochemical Society are not prepared to rely on this precedent. Already they are making known abroad their wish to attend the meeting of the Federation of European Biochemical Societies in Jerusalem in August, 1980.

It is not sufficient, they stress, that one or two leading Academicians should attend as official delegateswhat they are seeking is that any scientist from the Comecon bloc, willing to travel at his own expense, should be permitted to do so.

Vera Rich

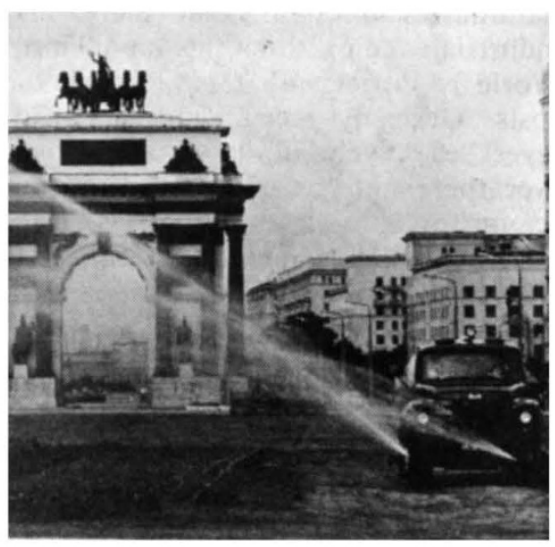

Moscow: Time for a clean-up

\section{Moscow's growing pollution problem}

INDUSTRIAL pollution in the Moscow region will increase by $150-200 \%$ by the end of the century, according to Dr Aleksandr M. Ryabchikov of Moscow State University. Already the city has spread across the ring road originally intended to confine it, and new developments are penetrating into the 'green belt' economy-dairy farming, market gardening, leisure zones and reservoirs, of what is described as the 'second peripheral belt'.

Purification installations are compulsory for all new industrial enterprises, but, according to Dr Ryabchikov, are "insufficiently advanced" and are very expensive, costing up to $40 \%$ of the capital cost of the plants. Only the use of abundant non-polluting energythermonuclear fusion and solar energy based on photochemistry, he said, can provide a lasting solution to the problem.

Dr Ryabchikov's suggestions follow a broad-based research programme on environmental measures recently been carried out in the geographical faculty at Moscow University. 